\title{
Evaluating the Effectiveness of an Organ and Tissue Donation Regulation on Ocular Donor Notification Rates in Clinical Settings
}

Frédéric Douville ${ }^{1^{*}}$ and Gaston Godin ${ }^{2}$

${ }^{1}$ Institut Universitaire De Cardiologie Et De Pneumologie de Québec, Canada

${ }^{2}$ Faculty of Nursing, Laval University, Canada

"Corresponding author: Frédéric Douville, Institut Universitaire De Cardiologie Et De Pneumologie de Québec, 2725, Chemin Sainte-Foy, Room Y-3495, Quebec (Quebec), G1V 4G5, Canada, Tel: 418 656-8711; E-mail: frederic.douville@fsi.ulaval.ca

Rec date: Mar 21, 2014, Acc date: Apr 22, 2014, Pub date: Apr 24, 2014

Copyright: $\odot 2014$ Douville F, et al. This is an open-access article distributed under the terms of the Creative Commons Attribution License, which permits unrestricted use, distribution, and reproduction in any medium, provided the original author and source are credited.

\begin{abstract}
Background: Despite the implementation of new regulations to increase organ and tissue donation, few regulations have been evaluated for their effectiveness in achieving this goal. Recently, the province of Quebec (Canada) modified Bill 125 to make notification of all potential donors to donation stakeholders mandatory in clinical settings. The purpose of this study was to evaluate the effectiveness of this new regulation on the potential ocular tissue donor notification rate in clinical settings.
\end{abstract}

Methods: This study used a pre-post design to determine the impact of the new regulation on the ocular tissue donor notification rate. The notification rate of potential ocular tissue donors was measured objectively among 26 departments of five clinical settings over a period of four months, beginning three months after the adoption of the new regulation (post-test measure); the pre-test value consisted in the notification rate during the same four-month period in the previous year. Data were analyzed using generalized estimating equations.

Results: The notification rate of ocular tissue donors prior to the change in the regulation (21.0\%) did not increase significantly after legislative changes $(21.6 \%)(x 2=0.01, p=0.93)$.

Conclusion: Despite making the notification of potential organ and tissue donors mandatory, the new regulation did not change the notification rate of ocular tissue donors. Policy formulation and policy implementation are two possible reasons for this failure. In particular, it is suggested that working closely with all relevant stakeholders at the time of policy formulation should facilitate implementation strategies.

Keywords: Government regulation; Evaluation studies; Tissue and organ procurement

\section{Introduction}

It is well documented that the demand for ocular tissue donation exceeds the supply, resulting in shortages [1-4]. In order to increase donation rates, many countries have in past decades implemented legislation regarding the organ donation process to ensure a legal framework to donation consent. As such, they have changed the donation process from an opt-in regulation to an opt-out regulation (presumed consent). The purpose was to increase donation rates, protect the rights of the donors, provide efficient allocation of the organs, and improve the quality and safety of transplants [5-9].

Nonetheless, in countries such as Canada where the donation process uses an opt-in system [10], the main strategies to increase organ and tissue donation are based either on the development of organ procurement organization (OPO) coordinators in clinical settings [11] or on the implementation of new regulations and health policies [5-7].

However, despite the implementation of new regulations to increase donation, few have been evaluated for their effectiveness to increase donation. Most published documents only reflect problems in the regulation without really evaluating its impact on donation $[6,9]$.
Rithalia et al. [10] conducted a systematic review of the effect of presumed consent legislation on donation rates and observed that donation rates after the introduction of such legislation were higher after their implementation.

In February 2011, the Ministry of Health in the province of Quebec (Canada) modified Bill 125, facilitating organ and tissue donation. The two main changes were 1) the implementation a consent registry to post-mortem removal of organs or tissues and 2) making mandatory notification to donation stakeholders of all potential organ and tissue donors in clinical settings.

The purpose of this study was to evaluate the effectiveness of Quebec's new Bill 125 on the rate of ocular tissue donor notifications in clinical settings.

\section{Methods}

\section{Design}

This study used a pre-post design to determine the impact of the new regulation on the ocular tissue donor notification rate. The main outcome was the ocular tissue donor notification rate, since eligibility criteria for this donation are quite large (all deceased patients that were 85 years old or less and not presenting systemic infection). Indeed, the new regulation stipulated that donation stakeholders must be 
Page 2 of 3

contacted for every potential tissue donor, thus suggesting that the ocular tissue donor notification rate is an appropriate variable to test the effect of this specific part of the Bill. The notification rate of potential ocular tissue donors was measured objectively among 26 departments of five hospital centres. The departments were chosen on the basis that they were likely to encounter ocular tissue donation, for example emergency departments, intensive care units, or palliative care units. Thereby, outpatient clinics or administrative departments were excluded. Also, all the selected departments were operated in clinical settings where OPO representatives coordinated donation. This criterion ensured that physicians in these departments had some knowledge to notify potential ocular tissue donors, since OPO representatives offer regular support to medical staff, heighten their awareness of the donation process and help them approach families.

This study received approval from the research ethics committee of the two institutions regrouping the five hospitals for a previous nursing intervention on ocular tissue donation rate.

\section{Data collection}

The ocular tissue donor notification rate was defined as the ratio between the achieved and potential number of ocular tissue donors. The objective data on the potential number of ocular tissue donors was obtained from the archives of each hospital. Among these potential ocular tissue donors, the achieved number of tissue donor notifications was obtained from the database of the provincial tissue bank for each department during each month of the study period.

\section{Evaluation periods}

Measures of donor notification rates were obtained before and after the adoption of the new regulation. However, in order to properly evaluate the effect of this new regulation, post-implementation measurement was obtained only after a three-month waiting period. The three-month period was decided to ensure senior medical service managers had enough time for dissemination of the new mandatory notification strategy. Then, the notification rate was measured over a period of four months. In order to control for possible seasonal effects in notification rate, the pre-implementation measure covered the same four-month period in the previous year.

\section{Statistical Analysis}

The impact of the Bill was assessed by comparing the difference in mean ocular tissue donor notification rates before and after the new regulation became effective. Ocular tissue donor notification rates were analyzed using generalized estimating equations. Analyses were executed with SAS version 9.2, using a bilateral level of significance of $5 \%$.

\section{Results}

The ocular tissue donor notification rates calculated at pre- and post-implementation of the new regulation are presented in Table 1. Contrast results for generalized estimating equation analysis showed no statistical difference between pre- and post-changes in the regulation $(\chi 2=0.07, \mathrm{p}=0.79)$. Both periods had a similar notification rate (before: $21.0 \%$; after: $21.6 \%$ ).

\begin{tabular}{|l|l|l|l|l|}
\hline Periods & $\begin{array}{l}\text { Referred } \\
\text { donors (n) }\end{array}$ & $\begin{array}{l}\text { Potential } \\
\text { donors (n) }\end{array}$ & $\begin{array}{l}\text { Notification } \\
\text { rate (\%) }\end{array}$ & Cl \\
\hline
\end{tabular}

\begin{tabular}{|l|l|l|l|l|}
\hline Pre & 98 & 466 & 21 & $-0.1-0.2$ \\
\hline Post & 99 & 459 & 21.6 & $-0.1-0.2$ \\
\hline Difference $^{2}$ & 1 & -7 & 0.6 & $-0.2-0.2$ \\
\hline
\end{tabular}

Table 1: The number of donors and notification rate per period

\section{Discussion}

To our knowledge, this is the first study to assess the impact of a new organ and tissue donation regulation on ocular tissue donor notification rates. The revised version of the Quebec Bill facilitating organ and tissue donation did not significantly increase the notification rate of ocular tissue donors during the four-month evaluation period, compared to the same period the previous year. Obviously, despite the implementation of the regulation making the notification of all potential ocular tissue donors to a donation stakeholder mandatory, the notification rate showed no improvement following the effective date.

This suggests that there could have been some deficiencies in the policy cycle [12-13] of the revised version of the bill facilitating organ and tissue donation. The stages of policy cycle include the following: 1) agenda setting; 2) policy formulation; 3) decision making; 4) policy implementation, and; 5) policy evaluation [12,13]. Two of these stages presented some shortcomings in the present case: policy formulation and policy implementation.

Policy formulation refers to actors involved in developing and refining policy options. These actors must have a level of knowledge of the subject and help resolve policy problems [13]. According to the Proceedings of National Assembly (Parliament of Quebec), government deputies and main stakeholders in the domain of organ donation attended debates and heard explanations regarding the revised bill modification. These actors surely had knowledge of the subject of donation and helped resolve policy problems. They agreed on the new policy formulation making the notification of donation stakeholders mandatory in clinical settings, as suggested by these debate excerpts from donation stakeholders:

"We welcome the mandatory notification that will rest to the role of senior medical service mangers (...)" (own translation).

“(...) (donation stakeholders) appreciate that the concept of mandatory notification [for the senior medical service managers] is introduced earlier in the paragraph, thereby emphasize the importance of acting quickly" (own translation).

However, the proceedings make it clear that one key group of actors was absent in the policy formulation on organ and tissue donation: senior medical service managers. The latter key players are the main targeted group in the amendment to the bill, since they are responsible for the implementation of organizational strategies to systematize the reference. Their absence from the discussions did not allow them to agree with the process of mandatory notification of potential donors. Their absence in the discussions at the time of elaboration of the revised regulation might therefore be one of the possible explanations for the lack of effect on the notification rate. This suggests the new Bill was poorly implemented [12]. 
Policy implementation refers to how policies are put into effect [12]. Governments use various kinds of instruments to make policies effective, whether substantive, procedural or combined [13]. In the revised Bill facilitating organ and tissue donation, one of the changes in the regulation was the adoption and implementation of a registry for post-mortem removal of organs or tissues. However, there were no governmental instruments or strategies to help implement this new tool for the notification of potential donors. Senior medical service managers were informed of the specificities of the Bill, but never had the time to develop and implement a strategy to ensure notification before the regulatory changes came into effect. Thus, one of the additional explanations for the lack of effect of the new bill on donor notification rate could be the observed flaws in policy implementation.

\section{Conclusion}

Despite making the notification of potential donors mandatory, the revised bill facilitating organ and tissue donation left the notification rate of ocular tissue donation unchanged. Among the possible explanations for the lack of effect are potential problems in policy formulation and policy implementation. In the future, new regulations regarding the donation process should be developed with the participation of all key stakeholders in order to favour appropriate policy formulation and facilitate the development of adapted strategies for implementation. Efforts to promote potential donors identification/notification by health professionals and to encourage patients and families from any demographic group to consent to donation should continue, since legislation does not seem to be the cure to organ and tissue shortage.

\section{Acknowledgements}

The authors acknowledge Myrto Mondor and Simon Olivier Fournier for the statistical analysis and support in writing.

\section{References}

1. Muraine M, Toubeau D, Menguy E, Brasseur G (2002) Analysing the various obstacles to cornea postmortem procurement. Br J Ophthalmol 86: 864-868.
2. Lawlor M, Dobbins T, Thomas KA, Billson F (2006) Consent for corneal donation: the effect of age of the deceased, registered intent and which family member is asked about donation. Br J Ophthalmol 90: 1383-1385.

3. Gaum L, Reynolds I, Jones MN, Clarkson AJ, Gillan HL, et al. (2012) Tissue and corneal donation and transplantation in the UK. Br J Anaesth 108 Suppl 1: i43-i47.

4. Geissler A, Paoli K, Maitrejean C, Durand-Gasselin J (2004) Rates of potential and actual cornea donation in a general hospital: impact of exhaustive death screening and surrogate phone consent. Transplant Proc 36: 2894-2895.

5. Tsao CI, Chou NK, Chi NH, Chen SC, Ko WJ, et al. (2012) The influence of the organ allocation policy on a patient's chances of undergoing heart transplantation and the posttransplantation survival rate. Transplant Proc 44: 881-882.

6. Coppen R, Friele RD, van der Zee J, Gevers SK (2010) The potential of legislation on organ donation to increase the supply of donor organs. Health Policy 98: 164-170.

7. Verheijde JL, Rady MY, McGregor JL, Friederich-Murray C (2009) Enforcement of presumed-consent policy and willingness to donate organs as identified in the European Union Survey: the role of legislation in reinforcing ideology in pluralistic societies. Health Policy 90: 26-31.

8. Farrell AM (2010) Adding value? EU governance of organ donation and transplantation. Eur J Health Law 17: 51-79.

9. Lai M (2010) Do we need to change our national organ donation policy? Hepatology 51: 1479-1482.

10. Rithalia A, McDaid C, Suekarran S, Myers L, Sowden A (2009) Impact of presumed consent for organ donation on donation rates: a systematic review. BMJ 338: a3162.

11. Bollinger RR, Heinrichs DR, Seem DL, Rosendale JD, Johnson KS, UNOS Council for Organ Availability United Network for Organ Sharing (2001) Organ procurement organization (OPO), best practices. Clin Transplant 15 Suppl 6: 16-21.

12. Howlett M, Ramesh M, Perl A (2009) Studying Public Policy: Policy Cycles \& Policy Subsystems. (Oxford University Press, Don Mills.

13. Howlett M (2002) Policy Development, In The Handbook of Canadian Public Administration. Oxford University Press, Don Mills 173-191. 